\title{
Pulmonary vascular candidiasis and use of central venous catheters in neonates
}

\author{
W F KNOX, ${ }^{*}$ V N HOOTON, A J BARSON \\ From the Departments of *Pathology and Bacteriology, St Mary's Hospital, Manchester
}

SUMMARY A retrospective study of infant deaths in this maternity hospital carried out from 1976-86 showed a recent increase in fatalities with systemic candidiasis. Ten of twenty five cases occurred between July 1985 and June 1986. Most of these infants had Candida plugging pulmonary vessels, often accompanied by vasculitis, thrombosis, and parenteral lipid embolism. The adoption of central venous catheters for prolonged parenteral feeding of very preterm infants may have accounted for this phenomenon. Over the same decade there was an increased incidence of Candida isolates from all admissions to the neonatal intensive care unit: the prolonged survival of very low birthweight infants and the use of multiple courses of antibiotics were also factors.

Systemic candidiasis is a recognised and serious complication of neonatal intensive care and is associated with a high mortality. ${ }^{2}$ It occurs particularly in very low birthweight infants who have received multiple courses of broad spectrum antibiotics and who are fed parenterally. ${ }^{2-4}$ Over the past 12 months we have been aware of an increase in the number of infant deaths with systemic candidiasis in our neonatal intensive care unit. Most of these infants had central venous catheters, and showed Candida within the pulmonary vessels and a pulmonary vasculitis, an association which has been described previously. ${ }^{5}$ The aim of this study was to review our experience of the pathology of this condition over 10 years.

\section{Material and methods}

Necropsy records of babies dying in the neonatal medical and surgical units at this hospital between January 1976 and June 1986 were reviewed for cases of systemic candidiasis. All necropsies included histological examination of haemotoxylin and eosin stained sections of all major organs and tissues, together with periodic acid Schiff stained sections where indicated, and microbiological culture of lung, and, in many cases, blood and cerebrospinal fluid. Systemic candidiasis was diagnosed when Candida pseudohyphae or yeast forms were seen histologically within tissues or blood vessels, or where positive

Accepted for publication 2 December 1986 blood or cerebrospinal fluid cultures were obtained. A case in which permission for post mortem examination was refused but which was known to have systemic candidiasis on the basis of positive blood culture before death was also included.

Candidal isolates from the medical neonatal intensive care unit (NICU) were also reviewed during this period. Before 1981 the base for routine culture was nutrient broth (Oxoid) and agar (Oxoid) with 5\% horse blood. Subsequently, Columbia blood agar base (Oxoid) was used, together with cultures on Sabouraud's dextrose agar (Oxoid) at $37^{\circ} \mathrm{C}$ for 48 hours. Since November 1979 it has been the policy to take rectal swabs routinely from all infants on the NICU.

\section{Results}

An increase in the number of candidal isolates from the NICU in the past 10 years occurred (fig 1), beginning in 1981: it was probably due in part to changes in culture policy with routine plating out on Sabouraud's medium. Over the same time period, however, there was a decline in the numbers of infants aged less than a week coming to necropsy, reflecting the longer survival of extremely premature infants as a result of intensive care. The commonest sites of isolation (table 1) were rectum, skin, urine, and umbilicus.

Between January 1976 and June 198625 infants died with evidence of systemic candidiasis (tables 2 and 3). Nearly all were of very low gestation (mean 27.2 weeks) and birthweight (mean $1028 \mathrm{~g}$ ) and had 
the complications associated with extreme prematurity. Most of the infants were cared for in the NICU, although a few (cases 5, 10, and 14) were treated in the neonatal surgical unit, and one (case 23) in the children's ward. Only eight of the infants were born in St Mary's Hospital, most being transferred from other hospitals within hours or days of birth. Most of the babies received multiple courses of antibiotics, and in some cases as many as seven different antibiotics were given before the onset of systemic candidiasis. All of the babies received intravenous fluids, and those who survived in excess of 14 days were fed parenterally. Most had umbilical arterial catheters, and 16 had indwelling central venous catheters usually inserted into the jugular vein. Although a few of the babies died in the second week of life, most lived longer (mean survival $37 \cdot 2$ days).

Table 1 Candida isolates from neonatal intensive care unit 1976-85

\begin{tabular}{|c|c|c|c|}
\hline Site & No \% & Site & No\% \\
\hline $\begin{array}{l}\text { Rectum } \\
\text { Skin } \\
\text { Urine } \\
\text { Umbilicus } \\
\text { Throat } \\
\text { Buttocks } \\
\text { ETT } \\
\text { Nose } \\
\text { Mouth } \\
\text { Blood }\end{array}$ & $\begin{array}{rr}265 & (32 \cdot 7) \\
85 & (10 \cdot 5) \\
76 & (9 \cdot 4) \\
61 & (7 \cdot 5) \\
60 & (7 \cdot 4) \\
47 & (5 \cdot 8) \\
44 & (5 \cdot 4) \\
34 & (4 \cdot 2) \\
33 & (4 \cdot 1) \\
20 & (2 \cdot 5)\end{array}$ & $\begin{array}{l}\text { Catheter tip } \\
\text { Gastric } \\
\text { Wound } \\
\text { Urine (SPA) } \\
\text { Ear } \\
\text { Eye } \\
\text { CSF } \\
\text { Vagina } \\
\text { Others }\end{array}$ & $\begin{aligned} & 18(2 \cdot 2) \\
& 17(2 \cdot 1) \\
& 17(2 \cdot 1) \\
& 8(1 \cdot 0) \\
& 8(1 \cdot 0) \\
& 6(0 \cdot 7) \\
& 3(0 \cdot 4) \\
& 3(0 \cdot 4) \\
& 5(0.6)\end{aligned}$ \\
\hline
\end{tabular}

ETT: Endotracheal tube.
Although Candida was isolated from superficial sites during life in most cases, in only five were positive blood cultures obtained (table 3 ). The organism was grown from cerebrospinal fluid in two cases and from urine in nine. At post mortem the organism was seen most commonly within the lungs (18 cases), followed by heart $(n=7)$, kidney $(n=7)$, peritoneum $(n=6)$, brain $(n=6)$, and adrenal $(4)$.

Pathologically the cases could be divided into four broad groups based on the site of infection (table 4).

\section{PULMONARY VASCULAR}

Candidal yeasts and occasionally pseudohyphae were present within medium and small pulmonary vessels (figs 2 and 3), often accompanied by recent or organising thrombus, inflammatory debris, and lipid material with the appearance of parenteral lipid (Intralipid, KabiVitrum) (fig 4). In many cases there was a necrotising pulmonary vasculitis (fig 5), although this appearance was sometimes seen in vessels which did not contain Candida, in addition to those which did. In this group organisms were not often seen within the airways and alveoli. In most cases, however, dissemination of yeasts, and, on occasion, pseudohyphae to other parts of the body had occurred. All 12 infants with pulmonary vascular candidiasis had central venous catheters, and of the 16 infants with a catheter, only three did not show this histological appearance. (Post mortem examination was not performed in the remaining case.) 
Table 2 Clinical data

\begin{tabular}{|c|c|c|c|c|c|c|c|}
\hline No & $\begin{array}{l}\text { Gestation } \\
\text { (weeks) }\end{array}$ & $\begin{array}{l}\text { Birth } \\
\text { weight }(g)\end{array}$ & $\begin{array}{l}\text { Survival } \\
\text { (days) }\end{array}$ & Diagnosis & $\begin{array}{l}\text { No of } \\
\text { antibiotics }\end{array}$ & $\begin{array}{l}\text { Umbilical } \\
\text { arterial catheter }\end{array}$ & $\begin{array}{l}\text { Central } \\
\text { venous } \\
\text { catheter }\end{array}$ \\
\hline $\begin{array}{l}1 \\
2 \\
3 \\
4 \\
5 \\
6 \\
7 \\
8 \\
9\end{array}$ & $\begin{array}{l}32 \\
29 \\
26 \\
30 \\
30 \\
26 \\
27 \\
25 \\
26\end{array}$ & $\begin{array}{r}1000 \\
1230 \\
695 \\
1140 \\
1400 \\
860 \\
1000 \\
940 \\
980\end{array}$ & $\begin{array}{r}60 \\
28 \\
13 \\
35 \\
64 \\
9 \\
14 \\
35 \\
56\end{array}$ & $\begin{array}{l}\text { IRDS } \\
\text { IRDS, pneumonia, jaundice } \\
\text { IVH, pneumonia } \\
\text { IVH, pneumonia } \\
\text { Ileal atresia, NEC } \\
\text { Birth asphyxia, IVH, jaundice } \\
\text { Birth asphyxia, pneumonia } \\
\text { Pneumonia, jaundice } \\
\text { Asphyxia, jaundice, IVH } \\
\text { hydrocephalus, CMV }\end{array}$ & $\begin{array}{l}4 \\
5 \\
3 \\
5 \\
6 \\
3 \\
4 \\
5 \\
6\end{array}$ & $\begin{array}{l}+ \\
? \\
? \\
+ \\
+ \\
+ \\
+ \\
+ \\
+\end{array}$ & $\begin{array}{l}+ \\
? \\
? \\
+ \\
+ \\
- \\
+ \\
-\end{array}$ \\
\hline $\begin{array}{l}10 \\
11 \\
12 \\
13 \\
14 \\
15 \\
16 \\
17\end{array}$ & $\begin{array}{l}26 \\
27 \\
26 \\
26 \\
25 \\
27 \\
23 \\
26\end{array}$ & $\begin{array}{r}960 \\
950 \\
1000 \\
790 \\
860 \\
800 \\
620 \\
1000\end{array}$ & $\begin{array}{r}25 \\
32 \\
31 \\
34 \\
8 \\
7 \\
43 \\
33\end{array}$ & $\begin{array}{l}\text { NEC } \\
\text { IRDS, IVH, transposition } \\
\text { Pneumonia, jaundice } \\
\text { IRDS, IVH, PVL } \\
\text { Jaundice, NEC, DIC } \\
\text { IRDS, IVH, renal failure } \\
\text { Birth asphyxia, jaundice, IVH } \\
\text { Asphyxia, IRDS, IVH, } \\
\quad \text { gastric perforation }\end{array}$ & $\begin{array}{l}3 \\
3 \\
5 \\
6 \\
4 \\
2 \\
5 \\
7\end{array}$ & $\begin{array}{l}+ \\
+ \\
+ \\
+ \\
+ \\
+ \\
+ \\
+\end{array}$ & $\begin{array}{l}- \\
\bar{t} \\
+ \\
+ \\
+ \\
+\end{array}$ \\
\hline $\begin{array}{l}18 \\
19 \\
20 \\
21 \\
22 \\
23 \\
24 \\
25\end{array}$ & $\begin{array}{l}24 \\
25 \\
26 \\
26 \\
26 \\
40 \\
29 \\
28\end{array}$ & $\begin{array}{r}780 \\
750 \\
1130 \\
938 \\
575 \\
2750 \\
1500 \\
1060\end{array}$ & $\begin{array}{r}63 \\
14 \\
31 \\
27 \\
55 \\
156 \\
23 \\
35\end{array}$ & $\begin{array}{l}\text { Ruptured oesophagus, IVH, PVL } \\
\text { Sepsis, jaundice, intestinal perforation } \\
\text { IVH, pneumonia, jaundice } \\
\text { IRDS, jaundice, IVH } \\
\text { IRDS, sepsis, jaundice, IVH } \\
\text { Congenital varicella } \\
\text { Asphyxia, jaundice, IVH } \\
\text { IRDS, pneumonia, BPD, IVH, PVL }\end{array}$ & $\begin{array}{l}6 \\
4 \\
7 \\
7 \\
4 \\
6 \\
7 \\
7\end{array}$ & $\begin{array}{l}+ \\
+ \\
+ \\
+ \\
+ \\
+ \\
+\end{array}$ & $\begin{array}{l}+ \\
+ \\
+ \\
+ \\
+ \\
+ \\
+ \\
+\end{array}$ \\
\hline
\end{tabular}

BPD: Bronchopulmonary dysplasia; CMV: cytomegalovirus; DIC: disseminated intravascular coagulopathy; IRDS: idiopathic respiratory distress syndrome; IVH: intraventricular haemorrhage; NEC: necrotising enterocolitis; PVL: periventricular leucomalacia.

Table 3 Pathological data

\begin{tabular}{|c|c|c|c|c|c|}
\hline Case No & Antemortem cultures & Post mortem cultures & Lungs & $\begin{array}{l}\text { Histology of } \\
\text { gastrointestinal tract }\end{array}$ & Others \\
\hline 1 & $\begin{array}{l}\text { Skin, umbilicus, stool, } \\
\text { urine }\end{array}$ & CSF & - & - & Heart, kidney, brain \\
\hline 2 & Trachea & Lung, blood, skin & Airways & + & \\
\hline 3 & $\begin{array}{l}\text { Throat, nose, } \\
\text { umbilicus, rectum }\end{array}$ & Lung, blood, rectum & Airways & + & \\
\hline 4 & Peritoneal fluid & Peritoneum & - & + & Peritoneum \\
\hline 5 & Skin & Lung, peritoneum & - & + & Peritoneum \\
\hline $\begin{array}{l}6 \\
7\end{array}$ & Ear, nose, throat & Lung, blood & Airways & + & Peritoneum \\
\hline 8 & UInomicus, UAC, EII & Lung, oiood & Vessels & $\stackrel{+}{-}$ & $\begin{array}{l}\text { Peritoneum } \\
\text { Heart, kidney, brain }\end{array}$ \\
\hline 9 & $\begin{array}{l}\text { Umbilicus, urine, } \\
\text { rectum }\end{array}$ & Lung, blood, urine & Airways & - & \\
\hline 10 & & Peritoneum & - & + & Peritoneum \\
\hline 11 & $\begin{array}{l}\text { Umbilicus, urine, } \\
\text { blood, rectum }\end{array}$ & $\begin{array}{l}\text { Lung, blood, urine, } \\
\text { pericardium }\end{array}$ & - & - & \\
\hline 12 & $\begin{array}{l}\text { Rectum, throat, ETT } \\
\text { urine, umbilicus, CSF }\end{array}$ & Lung, blood & Vessels & - & $\begin{array}{l}\text { Heart, kidney, brain, } \\
\text { marrow, liver, } \\
\text { adrenal, thymus, } \\
\text { thyroid }\end{array}$ \\
\hline 13 & - & - & Vessels & - & Inferior vena cava \\
\hline 14 & $\begin{array}{l}\text { Stomach, peritoneum } \\
\text { ETT }\end{array}$ & Lung, blood & Airways & - & $\begin{array}{l}\text { Peritoneum, bladder, } \\
\text { spleen }\end{array}$ \\
\hline 15 & $\begin{array}{l}\text { Stomach, ETT, } \\
\text { chest drain }\end{array}$ & Lung & - & + & Pleura \\
\hline 16 & & & Vessels & - & Brain \\
\hline 17 & Urine, buttocks & Blood & $\begin{array}{l}\text { Vessels, } \\
\text { airways }\end{array}$ & - & $\begin{array}{l}\text { Heart, kidney, brain, } \\
\text { spleen, adrenal }\end{array}$ \\
\hline $\begin{array}{l}18 \\
19\end{array}$ & Blood, urine (SPA) & Blood & Vessels & + & Kidney \\
\hline & & Lung, blood, CSF & Vessels & + & $\begin{array}{l}\text { Heart, kidney, } \\
\text { peritoneum, } \\
\text { thyroid, pituitary, } \\
\text { adrenal }\end{array}$ \\
\hline 20 & $\begin{array}{l}\text { Urine, blood, } \\
\text { peritoneum }\end{array}$ & (No necropsy) & & & \\
\hline 21 & Umbilicus & - & Vessels & - & Spleen \\
\hline $\begin{array}{l}22 \\
23\end{array}$ & Rectum, blood, urine & Lung & $\begin{array}{l}\text { Vessels } \\
\text { Vescels }\end{array}$ & - & \\
\hline 24 & $\begin{array}{l}\text { Urine, ETT, throat, } \\
\text { blood, CSF }\end{array}$ & $\begin{array}{l}\text { Lung, brain, liver, } \\
\text { blood }\end{array}$ & $\begin{array}{l}\text { Vessels, } \\
\text { airways }\end{array}$ & $\overline{+}$ & $\begin{array}{l}\text { Brain, kidney, heart, } \\
\text { liver, aorta, } \\
\text { adrenal, spleen, } \\
\text { thyroid }\end{array}$ \\
\hline 25 & - & - & Vessels & - & Heart \\
\hline
\end{tabular}


Table 4 Annual incidence of pulmonary vascular candidiasis, peritoneal candidiasis, respiratory tract candidiasis and other types of candidiasis in necropsies

\begin{tabular}{|c|c|c|c|c|c|c|c|c|c|c|c|}
\hline & $75-76$ & $76-77$ & $77-78$ & $78-79$ & $79-80$ & $\begin{array}{l}\left(\begin{array}{c}\text { July } \\
80-81\end{array}\right. \\
\text { - }\end{array}$ & e) $81-82$ & $82-83$ & $83-84$ & $84-85$ & $85-86$ \\
\hline Total No of cases & 1 & 0 & 2 & 1 & 1 & 4 & 1 & 2 & 2 & 1 & 10 \\
\hline Pulmonary vascular & & $\cdots$ & - & - & --- & 1 & $\ldots$. & 1 & 1 & - & 9 \\
\hline Peritoneal & & & - & 1 & 1 & 1 & 1 & - & 1 & $\ldots$ & $\cdots$ \\
\hline Airway & & & 2 & - & -- & 2 & -- & - & -- & - & - \\
\hline Other & 1 & $-\ldots$ & - & - & - & - & - & 1 & - & 1 & 1 \\
\hline
\end{tabular}

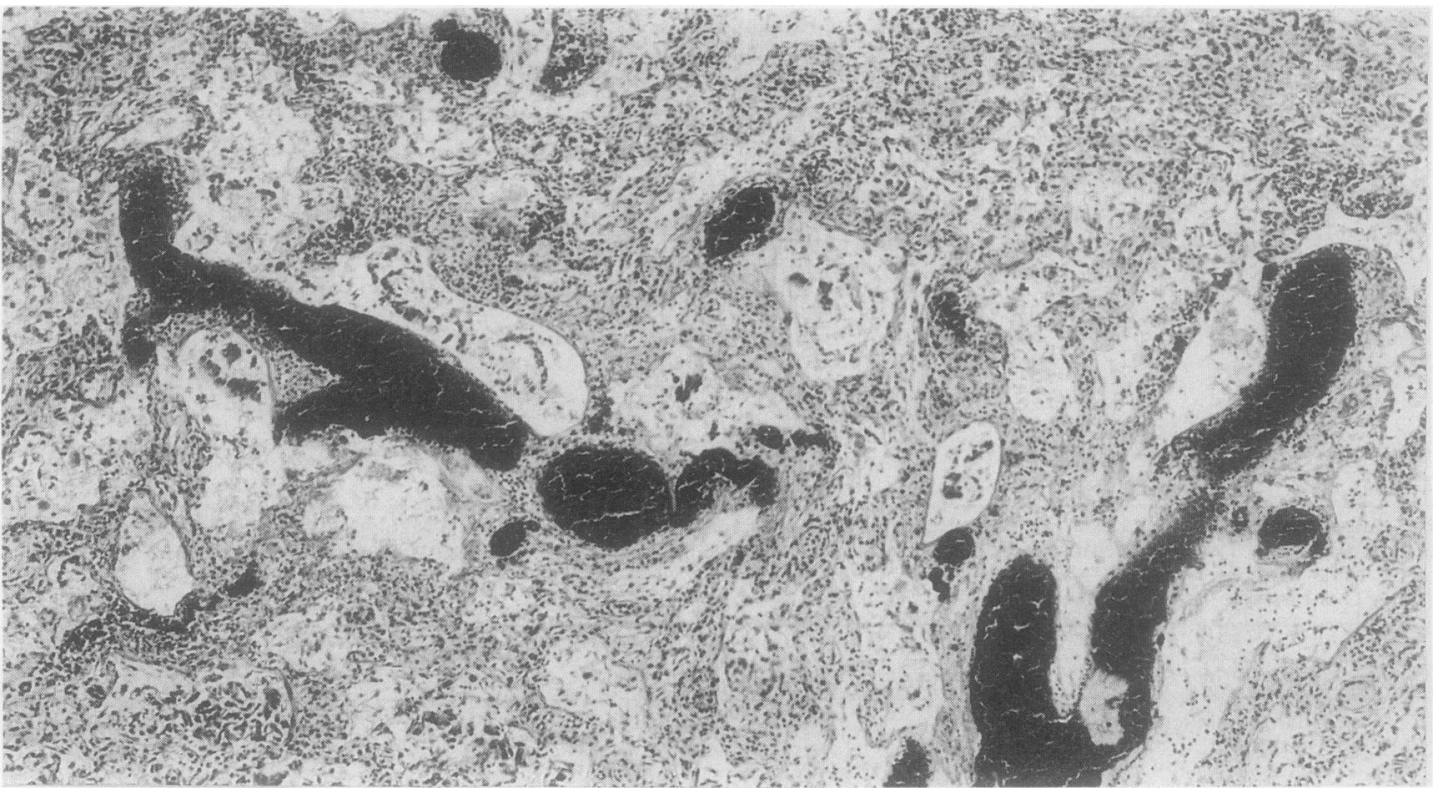

Fig 2 Candidal yeasts occluding medium and small pulmonary vessels. (Periodic acid Schiff stain.)

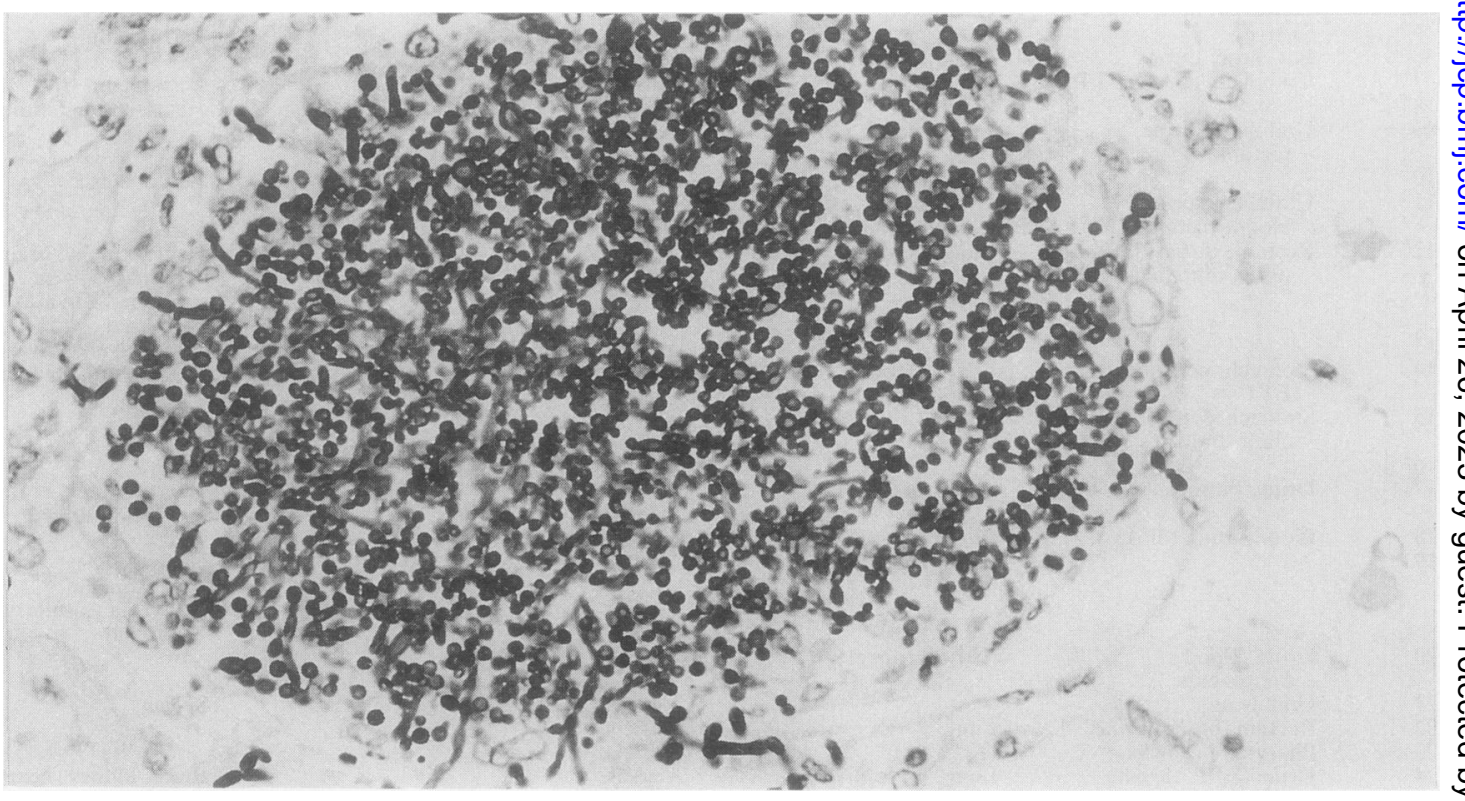

Fig 3 Candidal organisms, predominantly yeast forms, occluding pulmonary vessel, with early invasion of wall. (Periodic acido Schiff stain.) 


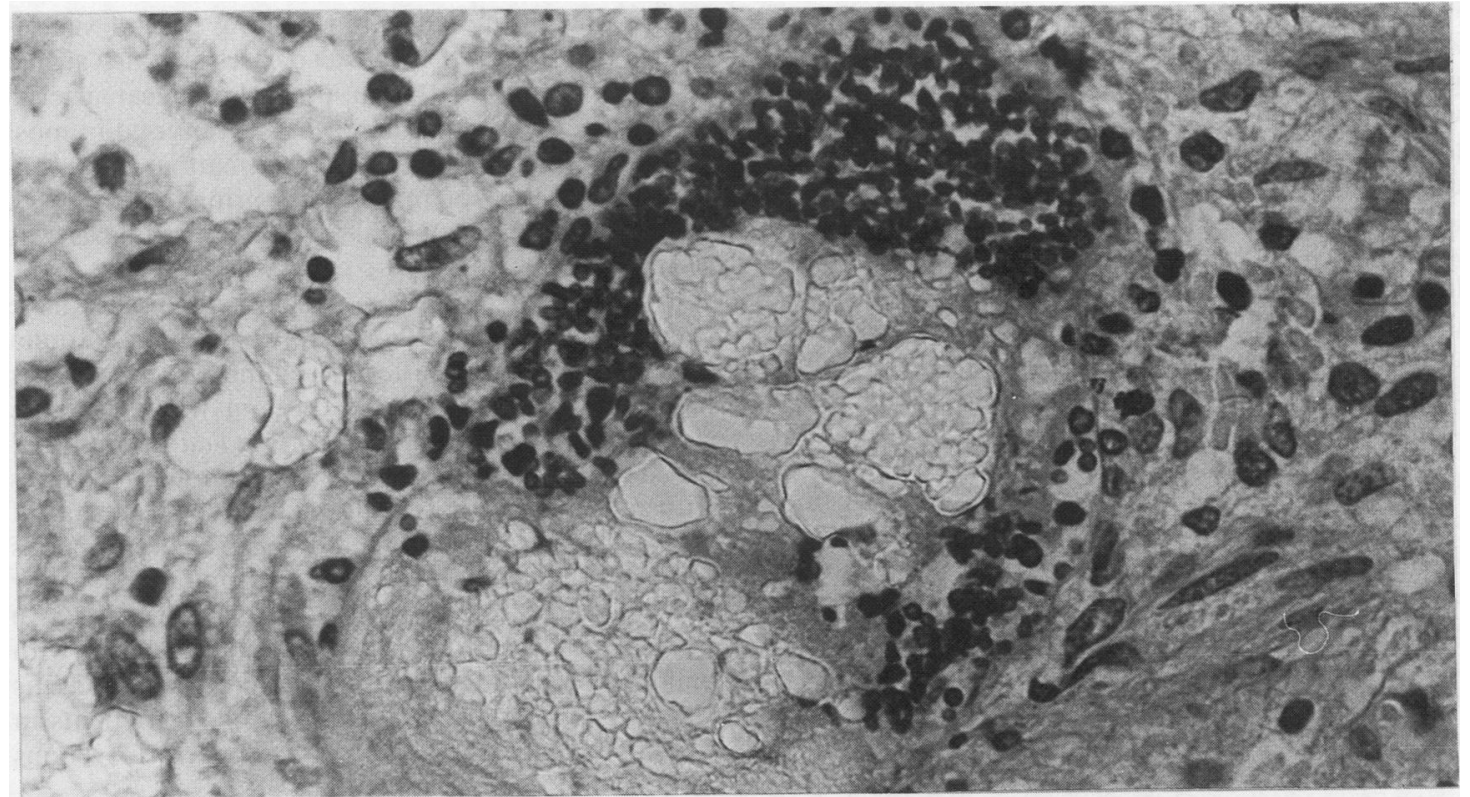

Fig 4 Candida and lipid droplets occluding small pulmonary artery. (Periodic acid Schiff stain.)

\section{PERITONEAL}

This group was characterised by Candida peritonitis following intestinal perforation. Candida pseudohyphae were seen in the peritoneum, within the intestinal lumen, and often in the bronchi and bronchioles. Occasionally organisms were disseminated elsewhere.

\section{AIR W A Y}

Histological evidence of the organism was confined to the gastrointestinal tract and airways, including bronchioles. Although post mortem blood cultures were positive, no invasion of the tissues by Candida was seen.

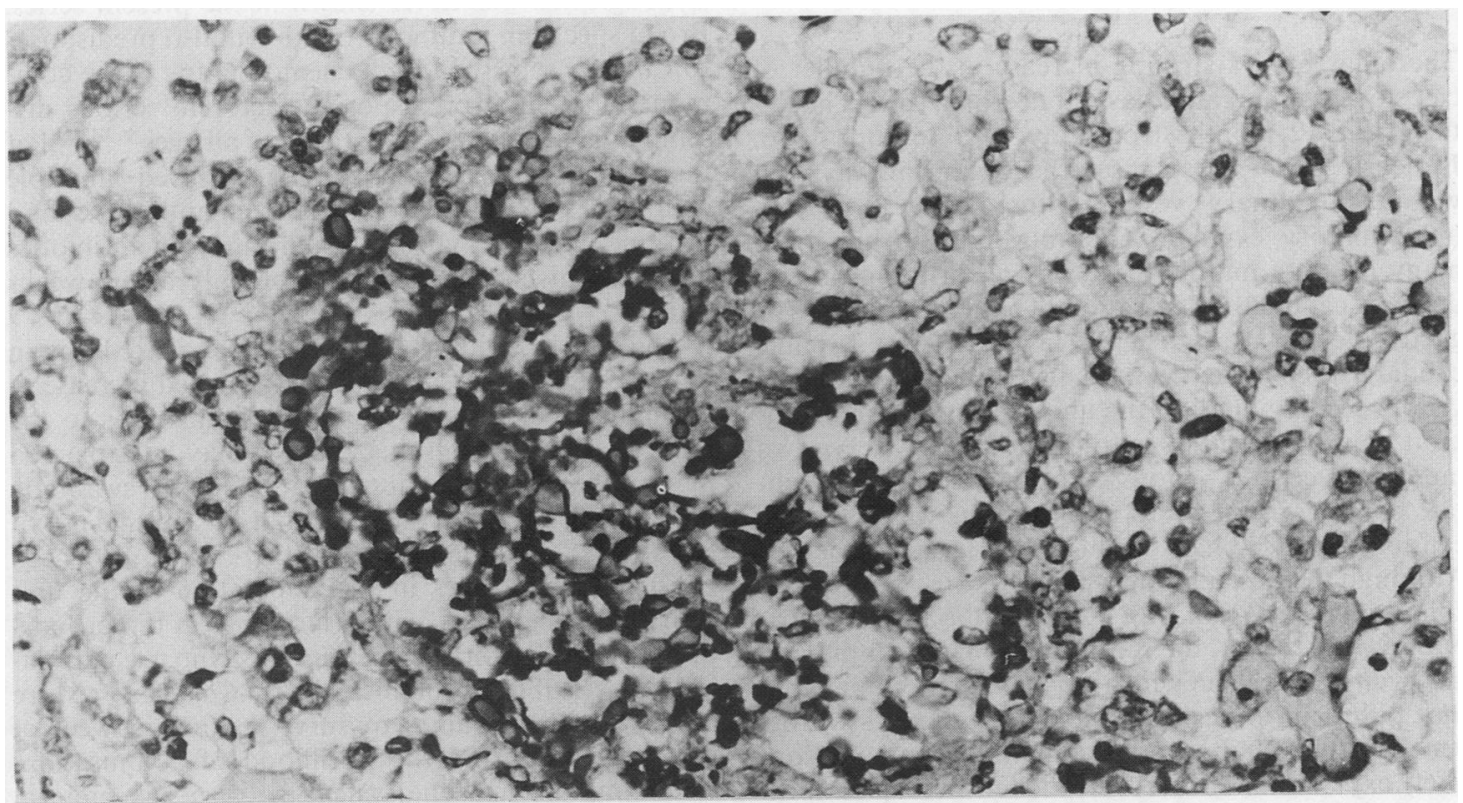

Fig 5 Candida within small pulmonary vessel with vasculitic changes. (Periodic acid Schiff stain.) 
OTHER

A few cases did not fit into any of the above three groups, either because no post mortem examination was performed, because Candida was not seen histologically despite positive blood cultures, or because a different pattern of infection was seen.

Table 4 shows the incidence of systemic candidiasis at necropsy over the study period: a noticeable increase in incidence in the 12 months from July 1985 to June 1986 occurred, and this increase comprised only cases with Candida within pulmonary vessels. In contrast, the other groups showed no recent rise in incidence.

A variety of histological appearances was seen in other organs. In the kidney Candida was seen most commonly within renal tubules, particularly in the medulla, with abscess formation and destruction of renal tissue in some cases. In one infant yeasts were present in afferent arterioles and glomerular capillaries, accompanied by focal necrosis of the glomerular tufts. Appearances in the brain ranged from yeasts within small cerebral and meningeal vessels to massive infiltration of cerebrum, cerebellum, and brain stem by pseudohyphae. Organisms were commonly seen in the periventricular region. In one case there was a striking granulomatous response, especially in the cerebellum with organisms present within giant cells. Cardiac disease included endocarditis with valvular vegetations, yeasts within small myocardial vessels, and myocarditis with necrosis.

\section{Discussion}

There has been a striking increase in the number of cases of systemic candidiasis at necropsy at this hospital in the 12 months from July 1985 to June 1986. In nearly all of these cases the organism was seen within pulmonary vessels, often with thrombus, inflammatory exudate, and intralipid, although in many of these infants there was no histological evidence of candidal colonisation of either the airways or gastrointestinal tract. The rise in incidence of systemic candidiasis coincided with an increased use of central venous feeding lines on the unit. It seems that a common portal of entry in these infants was via an indwelling central venous catheter inserted to facilitate parenteral nutrition. Most infants with systemic candidiasis also had umbilical arterial catheters. Although there is no doubt that these are occasionally colonised by Candida with consequent systemic distribution of the yeast, the recent rise in fatal candidiasis has been in infants in which Candida predominated in the pulmonary vessels (table 4), where systemic venous rather than arterial contamination is a more likely explanation. Moreover, the few necropsies with pulmonary vascular candidiasis, which occurred before the routine adoption of long central venous 0 catheters in July 1985, were also cases in which such a $\underset{5}{*}$ venous catheter had been used. Umbilical arterial으. catheters, on the other hand, have been used in most $\vec{F}$ seriously ill infants on the intensive care unit to mon- $\frac{\text { P }}{9}$ itor blood gases for many years prior to July 1985 , 읃 when the increase in fatal systemic candidiasis was $\frac{\sigma}{\bar{\omega}}$ seen.

The different patterns of pulmonary disease have $\stackrel{\mathbb{Q}}{\varrho}$ been noted by other workers. Kassner et al found that the commonest pattern of pulmonary candidiasis $\vec{\circ}$ in infants was the embolic type, in which thrombi ${ }_{-}^{\circ}$ containing large numbers of Candida spores and $\vec{\omega}$ pseudohyphae were present in pulmonary arteries with multiple haemorrhagic infarcts. ${ }^{6}$ The portal of $\frac{7}{0}$ entry in these was considered to have been venous $\overrightarrow{0}$ catheters. Less commonly, bronchopulmonary (air ir space invasive) and disseminated (capillary invasive) forms were seen. Rose et $\mathrm{al}$, in a study of adults with pulmonary candidiasis, found a necrotising vasculitis $\frac{\text { ? }}{\supset}$ affecting pulmonary vessels in five of six patients in whom the portal of entry had been a venous catheter. $^{5}$

Systemic candidiasis is known to complicate the use $\overrightarrow{0}$ of indwelling vascular catheters for parenteral nutri- $\underset{v}{ }$ tion. $^{7-9}$ The risk of infection increases with the $\square$ length of time the catheter has been in situ. ${ }^{89}$ The organisms can enter the body along the side of the catheter, and the tip provides a nidus for colonisation and subsequent embolisation of Candida. Parenteral $\frac{}{\mathrm{D}}$

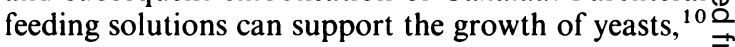
although this was never shown in the present series. $\overrightarrow{\overrightarrow{0}}$ Broad spectrum antibiotic treatment also predisposes to Candida sepsis. Indeed, chemotherapy is the commonest potential predisposing factor to serious disseminated candidiasis in patients of all ages. ${ }^{811}$ All of응 the patients in our series had received multiple 0 courses of parenteral broad spectrum antibiotics, and 3 . in some cases as many as seven different antibiotics $\delta$ had been given over a period of only a few weeks (table 2).

The rise in fatalities from systemic candidiasis in the NICU was preceded by a pronounced increase in the number of isolates among all admissions to the unit (fig 1). Although this increase may be explained $\widetilde{\sigma}$ in part by the introduction of routine rectal swabbing $N$ of all NICU infants in 1979, and of the routine use of Sabouraud's medium in 1981, there have also been $\sigma$ considerable changes in the population of the unit over the past decade, with a large rise in the proportion of very low birth weight infants who are particularly susceptible to colonisation by Candida. ${ }^{12}$ More of these very tiny babies are surviving the first week of $\overline{0}$ life, thus increasing the likelihood of colonisation. The immature immune system in these sick preterm $\frac{\rho}{\mathbb{D}}$ infants may be less capable of dealing with the $\frac{0}{\sigma}$ 
organism than the relatively more mature infants who populated the unit before 1981 .

The nature of the work of a neonatal intensive care unit is such that it is difficult to see how candidal colonisation, antibiotics, and catheterisation can be avoided. Our enquiries, however, suggest that long central intravenous lines via the jugular vein pose a particular risk.

We thank Drs M L Chiswick and D G Sims for access to their clinical records. W F K is a MRC Research Training Fellow.

\section{References}

I Faix RG. Systemic Candida infections in infants in intensive care nurseries: high incidence of central nervous system involvement. J Pediatr 1984;105:616-22.

2 Johnson DE, Thompson TR, Green TP, Ferrieri P. Systemic candidiasis in very low-birth-weight infants ( $<1500$ grams). Pediatrics 1984;73:138-43.

3 Baley JE, Kliegman RM, Fanaroff AA. Disseminated fungal infections in very low-birth-weight infants: clinical manifestations and epidemiology. Pediatrics 1984;73:144-52.

4 Smith H, Congdon P. Neonatal systemic candidiasis. Arch Dis Child 1985;60:365-9.
5 Rose HD, Sheth NK. Pulmonary candidiasis. A clinical and pathological correlation. Arch Intern Med 1978;138:964-5.

6 Kassner EG, Kauffman SL, Yoon JJ, Semiglia M, Kozinn PJ, Goldberg PL. Pulmonary candidiasis in infants: clinical, radiologic and pathologic features. $\mathrm{Am} J$ Radiol 1981;137:707-16.

7 Curry CR, Quie PG. Fungal septicaemia in patients receiving parenteral hyperalimentation. New Engl J Med 1971;285:1221-5.

8 Williams RJ, Chandler JG, Orloff MJ. Candida septicaemia. Arch Surg 1971;103:8-11.

9 Grisoni ER, Mehta SK, Connors AF. Thrombosis and infection complicating central venous catheterisation in neonates. $J$ Pediatr Surg 1986;21:772-6.

10 Melly MA, Meng HC, Schaffner W. Microbial growth in lipid emulsions used in parenteral nutrition. Arch Surg 1975; 110:1479-81.

11 Bernhardt HE, Orlando JC, Benfield JR, Hirose FM, Foos RY. Disseminated candidiasis in surgical patients. Surg Gynecol Obstet 1972;134:819-25.

12 Baley JE, Kliegman RM, Boxerbaum B, Fanaroff AA. Fungal colonisation in the very low birth weight infant. Pediatrics 1986;78:225-32.

Requests for reprints to: Dr AJ Barson, Department of Pathology, St Mary's Hospital, Whitworth Park, Manchester M13 0JH, England. 